\title{
Ischemia-modified albumin levels in professional male soccer players before and after training
}

\author{
Profesyonel futbolcularda egzersiz öncesi ve sonrası iskemi modifiye albumin düzeyleri
}

Can DUMAN, Tuncay ÇOLAK, Belgin BAMAÇ, İmran GÖKER, Serap ÇOLAK, Aydın ÖZBEK

\begin{abstract}
Objectives: The ischemia-modified albumin (IMA) test is a promising indicator of myocardial ischemia in the early diagnosis of the acute coronary syndrome (ACS). Recent studies examining alterations in IMA levels caused by myocardial ischemia that develops during exercise have shown contradictory results. There has been an increase in severe exercise-related cardiac events in football. We therefore, assessed IMA levels before and after exercise in professional soccer players in order to examine the effect of the exercise on IMA levels.

Methods: Blood was collected from professional soccer players before and after exercise. IMA levels were measured by using spectrophotometric methods, and the albumin levels were measured in an autoanalyzer.

Results: The average pre- and post exercise IMA levels of 16 soccer players were found to be $0.438 \pm 0.071$ and $0.386 \pm 0.069$, respectively. The pre- and post exercise albumin levels of the same group were $4.08 \pm 0.20 \mathrm{~g} / \mathrm{dL}$ and $4.21 \pm 0.19 \mathrm{~g} / \mathrm{dL}$, respectively. There was a strong negative correlation between post exercise IMA and albumin levels, which was statistically significant $(\mathrm{r}=-0.535 . \mathrm{p}=0.033)$.

Conclusion: IMA levels should be examined not only in noncardiac pathologies, but also in specific serum albumin concentrations and in individuals practicing vigorous sport activities.
\end{abstract}

Key words: Ischemia, Ischemia-modified albumin, Albumin, Exercise, Soccer

\footnotetext{
Can Duman $(\bowtie)$

Department of Biochemistry, School of Medicine, Canakkale Onsekiz Mart

University, Çanakkale, Turkey

e-mail: canduman71@hotmail.com

Tuncay Çolak, Belgin Bamaç, Aydın Özbek

Department of Anatomy, School of Medicine, Kocaeli University, Kocaeli, Turkey

İmran Göker

Department of Health Administration, School of Economics \& Administrative Sciences, Okan University, Istanbul, Turkey

Serap Çolak

School of Physical Education and Sports, Kocaeli University, Kocaeli, Turkey
}

Submitted/Gönderilme: 26.082012 - Accepted/Kabul: 23.10.2012
ÖZET

Amaç: İskemi modifiye albumin (IMA), akut koroner sendromun erken tanisinda myokard iskemisinin bir belirteci olarak umud vadeden bir testtir. Ancak egzersiz sırasında gelişen iskeminin IMA düzeylerinde yolaçtığı değişimi inceleyen son çalışmalar çelişkili sonuçlar saptamıştır. Öte yandan futbolcularda egzersizle ilgili ciddi kardiyak olaylarda da artış vardır. Bu nedenle biz IMA düzeylerine egzersizin etkisini araştırmak için profesyonel futbol oyuncularında egzersiz öncesi ve sonrası IMA düzeylerini değerlendirdik.

Yöntem: Profesyonel futbolculardan egzersiz öncesi ve sonrası kan örnekleri toplandı. IMA düzeyleri spektrofotometrik metodların kullanımı ile ve albumin düzeyleri de otomatik analizör cihazında ölçüldü.

Bulgular: On alt1 futbolcunun egzersiz öncesi ve sonras1 ortalama IMA düzeyleri sirasiyla $0.438 \pm 0.071$ and $0.386 \pm 0.069$ olarak saptand1. Ayn1 grubun egzersiz öncesi ve sonras1 ortalama albumin düzeyleri ise sirasiyla $4.08 \pm 0.20 \mathrm{~g} / \mathrm{dL}$ and $4.21 \pm 0.19 \mathrm{~g} / \mathrm{dL}$ olarak ölçüldü. Egzersiz sonrası IMA ve albumin düzeyleri arasında istatistiksel olarak anlamlı güçlü bir negatif korelasyon vardı $(r=-0.535 . p=0.033)$.

Sonuç: IMA düzeyleri sadece kardiyak olmayan patolojilerde değil özgül serum albumin konsantrasyonlarında ve şiddetli spor aktivitelerinde bulunan bireylerde de değerlendirilmelidir.

Anahtar kelimeler: İskemi, İskemi modifiye albumin, Albumin, Egzersiz, Futbol

\section{Introduction}

Currently, several sensitive and specific methods are available to identify myocardial necrosis. However, it remains a challenge to diagnose ischemia that develops just before necrosis, and hence, probably induces the necrosis in the early phases [1]. There is no gold standard to assess myocardial ischemia; although the ischemia-modified albumin (IMA) test, referred to as the albumin cobalt binding (ACB) test, is a promising early indicator for the detection of myocardial ischemia before the onset of necrosis [2]. Importantly, IMA levels increase in ischemic states which do not originate from cardiac conditions in which extracellular hypoxia, acidosis, and free radical damage occurs as well [2]. Changes in IMA levels have also been observed in studies related to exercise, which is another situation that leads to ischemia; however, the effect of exercise on IMA levels is not clear. Lippi et al. 
reported increases in IMA levels during aerobic endurance exercises in healthy individuals [3]. Kurz et al. found similar results in patients undergoing exercise stress tests [4]. In contrast, Piechota et al. detected a reduction in IMA levels after exercise in patients who had previously been diagnosed with coronary atherosclerosis [5]. Furthermore, they reported that this reduction was parallel to an increase in the albumin concentration.

Football is one of the most energy-demanding sports activities, and also football training includes a great deal of weight-lifting activities. Strenuous exercise may lead to transitory myocardial ischemia and myocardial stress, possibly inducing increased levels of IMA. Thus, we examined the changes in IMA levels in professional soccer players before and after training.

\section{Methods}

In the present study $5 \mathrm{~mL}$ of blood were obtained from each player of a soccer team in the Second League. The study was approved by the Ethics Committee of Kocaeli University. All players were informed about the study procedure and purpose, and informed consent was obtained from each player.

The study group consisted of 16 male soccer players with a mean age of $26.25 \pm 5.42$ years. The running exercise programs of soccer players were set as follows:

- warm-up running for 20 minutes;

- a 7.5-minute running in which the pulse was kept at 150-160 per minute; and

- a cool-down period with 2.5 minutes of jogging.

This set of exercises was repeated three times. Then, the exercise period was completed with a 10-minute running period during which the pulse was maintained at 150-160 per minute again.

The blood samples were collected in tubes without preservatives. The samples were allowed to form clots for 30 minutes and then centrifuged at $2500 \mathrm{~g}$ for 10 minutes to separate the serum. The serum samples were tested immediately. The ACB test was performed according to the method defined by Bar-Or et al. [6]. According to this method, $200 \mu \mathrm{L}$ of serum is added to a water solution containing $50 \mu \mathrm{L}$ of $0.1 \%$ cobalt chloride $\left(\mathrm{CoCl}_{2} \cdot 6 \mathrm{H}_{2} \mathrm{O}\right.$; Sigma, St. Louis, MO, USA). The mixture was stirred gently and kept to stand at room temperature for 10 minutes. Then, $50 \mu \mathrm{L}$ of dithiothreitol (DTT) solution with $1.5 \mathrm{mg} / \mathrm{mL} \mathrm{H}_{2} \mathrm{O}$ $\left(\mathrm{C}_{4} \mathrm{H}_{10} \mathrm{O}_{2} \mathrm{~S}_{2}\right.$; Sigma, St. Louis, MO, USA) was added. After 2 minutes, $1 \mathrm{~mL}$ of $0.9 \% \mathrm{NaCl}$ was added. Afterwards, the absorbance of the reaction mixture was measured with a spectrophotometer at $470 \mathrm{~nm}$. A sample without DTT was used as a blank sample. The results were reported in absorbance units (ABSU). Serum albumin concentrations were studied with the bromcresol green method in a modular analytics automated analyzer (Roche Diagnostics).
Table I. The IMA and albumin values before and after exercise (mean $\pm \mathrm{SD})$

\begin{tabular}{lccc}
\hline & Before Exercise & After Exercise & $\mathrm{p}$ \\
\hline IMA (ABSU) & $0.438 \pm 0.071$ & $0.386 \pm 0.069$ & 0.016 \\
Albumin $(\mathrm{g} / \mathrm{dL})$ & $4.08 \pm 0.20$ & $4.21+0.19$ & 0.003 \\
\hline Values shown are mean \pm standard deviation $($ mean $\pm \mathrm{SD}), \mathrm{ABSU}=$ absorbance units
\end{tabular}

The data of the study were analyzed by using the SPSS Ver. 15.0. Wilcoxon Rank Sum and Spearman Correlation tests were used for the analyses of the study. The statistical significance level was set at 0.05 .

\section{Results}

In this study, 16 soccer players in total were investigated. The mean age was $26.25 \pm 5.42$. The mean duration in years of active sport was $8.9 \pm 4.7$ and the mean BMI level was 23.6 \pm 0.9 . The pre- and post exercise IMA levels of the investigated 16 soccer players were $0.438 \pm 0.071$ and $0.386 \pm 0.069$ respectively. The pre- and post exercise albumin levels were $4.08 \pm 0.20 \mathrm{~g} / \mathrm{dL}$ and $4.21 \pm 0.19 \mathrm{~g} / \mathrm{dL}$. There was a strong negative correlation between post exercise IMA and albumin levels $(r=-0.535 . p=0.033)$, which was statistically significant. The correlation found between age, years of active sport, BMI and IMA levels was nonsignificant (Tables I and II).

\section{Discussion}

The mechanism of exercise-related sudden death in young competitive athletes includes a number of triggers, such as acute myocardial ischemia, sympathetic stimulation, and abrupt hemodynamic changes, leading to life-threatening ventricular arrhythmias. During exercise, physical and metabolic changes occur which lead to an increased risk of acute coronary complications and life-threatening myocardial ischemia [7].

Table II. The correlations between IMA, Age, BMI and years of sports activities

\begin{tabular}{lcc}
\hline & $\mathrm{r} *$ & $\mathrm{p}$ \\
\hline Post exercise IMA-Albumin levels & -0.535 & 0.033 \\
Post exercise IMA-Age level & -0.262 & 0.327 \\
Post exercise IMA-BMI level & 0.141 & 0.602 \\
Post exercise IMA- years of sports & -0.207 & 0.441 \\
Change in IMA vs Albumin levels & -0.133 & 0.624 \\
Change in IMA vs Age & -0.390 & 0.135 \\
Change in IMA vs BMI & 0.097 & 0.720 \\
Change in IMA vs e years of sports & -0.107 & 0.694 \\
\hline
\end{tabular}

*: Spearman's correlation test 
IMA is an early indicator of cardiac ischemia which develops before necrosis [8,9]. However, few studies have been carried out in patients with stable coronary atherosclerotic heart disease [10].

A change in IMA levels does not indicate cardiac pathology only; IMA levels are also elevated in individuals with skeletal muscle ischemia. The mechanism which plays a role in the formation of IMA during ischemia is unclear; however, ischemia, hypoxia, acidosis, and the formation of free radicals may alter the ability of three amino acids (aspartate, alanine, and histidine) at the N-terminus of albumin to bind free metal atoms, including cobalt. Due to these factors, the binding capacity of these amino acids is reduced. The ACB test is based on these biochemical alterations $[11,12]$.

The study by Troxler et al. revealed that in major arterial surgical procedures, skeletal muscle ischemia led to increased IMA levels [13]. Similar results were also reported by Montagnana et al. during orthopedic surgical procedures [14].

On the other hand, changes in IMA levels have also been investigated in studies related to exercise where changes in IMA levels also lead to ischemia. However, earlier studies investigating the effect of exercise on IMA levels have revealed different results. For instance, Kurz et al. observed that there was an increase in IMA levels 4 hours after an exercise stress test [4] and Lippi et al. also observed similar increases in IMA levels after aerobic strength exercises applied to healthy individuals [3], possibly because the increase in oxygen consumption in the cells caused by exercise results in an ischemic state, and thus the IMA levels increase. However, different results were reported in a study performed in marathoners where IMA levels after the race decreased; a situation which contradicted expectations [15]. Middleton et al. generated similar results in a study conducted in the London marathon in 2004 [16]. Roy et al. observed that IMA levels during muscle ischemia caused by exercise decreased below basal levels [17]. Piechota et al. [5] detected a reduction in IMA levels after exercise in patients previously diagnosed with coronary atherosclerosis. Furthermore, they observed that this reduction was parallel to the increase in albumin concentration. Therefore, they emphasized that the use of IMA could be misleading in myocardial ischemia induced by exercise due to the increase in albumin concentrations. We also observed a decrease in IMA levels after exercise, which is consistent with the findings of these other studies [5, 15-17].

Moreover, we detected increases in albumin concentrations which correspond to decreases in IMA levels after exercise, as indicated by Piechota et al. [5]. Similar findings were reported by Zapico-Muniz et al. [18]. Thus, we have suggested that physiologic processes, such as hemoconcentration caused by exercise [19] or transport of free fatty acids in large amounts to tissues as an energy source [16], increase the albumin concentration per unit blood volume. While the cobalt binding capacity of each albumin molecule exposed to ischemia is reduced, the increase in the quantity of albumin in a unit volume of blood causes greater cobalt binding, which constitutes a contradiction, and which leads to a false decrease in IMA absorbance. The strong negative relationship between albumin and IMA values was also reported in the study of Zapico-Muniz et al. [18]. In addition, IMA levels are influenced significantly by a wide array of physiologic variables, including exercise and hydration [20]. It is not clear what kinds of interference the physiopathologic processes caused by exercise can produce in IMA measurements. One of the issues debated in this context is lactate interference. It has been reported that lactate levels, which increase due to exercise, reduce IMA values $[17,18]$.

\section{Conclusion}

This is the first study that has reported decreased IMA levels after training in professional soccer players. Albumin concentrations, which increase after soccer training, may cause a decrease in IMA levels, and this increase was considered to be a factor interfering with IMA measurements. Therefore, IMA measurements on their own may not be reliable for assessing ischemia which develops during soccer training.

\section{References}

1. Roy D, Quiles J, Aldama G, et al. Ischemia Modified Albumin for the assessment of patients presenting to the emergency department with acute chest pain but normal or non-diagnostic 12-lead electrocardiograms and negative cardiac troponin T. Int J Cardiol 2004; 97: 297-301. doi:10.1016/ j.ijcard.2004.05.042

2. Christenson RH, Dull SH, Sanhai WR, et al. Characteristics of an Albumin Cobalt Binding Test for assessment of acute coronary syndrome patients: A Multicenter Study. Clin Chem 2001; 47: 464-70.

3. Lippi G, Montagnana M, Guidi GC. Predicting cardiac outcome. Can Med Assoc J 2005; 173: 1206-7. doi:10.1503/cmaj.1050168

4. Kurz K, Voelker R, Zdunek D, et al. Effect of stress-induced reversible ischemia on serum concentrations of ischemia-modified albumin, natriuretic peptides and placental growth factor. Clin Res Cardiol 2007; 96: 152-9. doi:10.1007/s00392-007-0469-5

5. Piechota WN, Wierzbowski R, Piechota WT, Bejm J, Gielerak G. $\mathrm{N}$-terninal pro-brain natriuretic peptide (NT-proBNP) and ischemia modified albumin (IMA) in exercise induced ischemia in patients with stable coronary artery disease. Pol Arch Med Wewn 2006; 116: 640-7.

6. Bar-Or D, Lau E, Winkler JV. A novel assay for cobalt-albumin binding and its potential as a marker for myocardial ischemia-A preliminary report. The J Emerg Med 2000; 19: 311-3. doi:10.1016/ S0736-4679(00)00255-9

7. Corrado D, Migliore F, Basso C, Thiene G. Exercise and the risk of sudden cardiac death. Herz 2006; 31: 553-8. doi:10.1007/s00059-0062885-8

8. Siasos G, Tousoulis D, Athanasiou D, et al. Novel risk factors related to stable angina. Curr Pharm Des 2012; 18: [Epub ahead of print].

9. Kehl DW, Iqbal N, Fard A, Kipper BA, De La Parra Landa A, Maisel AS. Biomarkers in acute myocardial injury. Transl Res 2012; 159: 252-64. doi:10.1016/j.trsl.2011.11.002

10. Zhong Y, Wang N, Xu H, Hou X, Xu P, Zhou Z. Ischemia-modified albumin in stable coronary atherosclerotic heart disease: clinical 
diagnosis and risk stratification. Coron Artery Dis 2012; 23: 538-41. doi: 10.1097/MCA.0b013e328358a5e9

11. Montagnana M, Lippi G, Regis D, et al. Evaluation of cardiac involvement following major orthopedic surgery. Clin Chem Lab Med 2006; 44: 1340-6. doi:10.1515/CCLM.2006.256

12. Refaai MA, Wright RW, Parvin CA, Grouowski AM, Scott MG Eby CS. Ischemia-modified albumin increases after skeletal muscle ischemia during arlhroscopic knee surgery. Clin Chim Acta 2006; 366: 264-8. doi:10.1016/j.cca.2005.10.020

13. Troxler M, Thompson D, Homer-Vanniasinkam S. Ischaemic skeletal muscle increases serum ischaemia modified albumin. Eur J Vasc Endovasc Surg 2006; 31: 164-9. doi:10.1016/j.ejvs.2005.06.019

14. Montagnana M, Lippi G, Volpe A, et al. Evaluation of cardiac laboratory markers in patients with systemic sclerosis. Clin Biochem 2006; 39: 913-7. doi:10.1016/j.clinbiochem.2006.03.016

15. Apple FS, Quist HE, Otto AP, Mathews WE, Murakami MM. Release characteristics of cardiac biomarkers and ischemia-modified albumin as measured by the albumin cobalt-binding test after a marathon race. Clin Chem 2002; 48: 1097-100.
16. Middleton N, Shave R, George K, et al. Novel application of flow propagation velocity and ischemia-modified albumin in analysis of postexercise cardiac function in man. Exp Physiol 2006; 91: 511-9. doi:10.1113/ expphysiol.2005.032631

17. Roy D, Quiles J, Sharma R, et al. Ischemia-modified albumin concentrations in patients with peripheral vascular disease and exercise-induced skeletal muscle ischemia. Clin Chem 2004; 50: 1656-60. doi:10.1373/clinchem.2004. 031690

18. Zapico-Muniz E, Santalo-Bel M, Merce-Muntanola J, et al. Ischemiamodified albumin during skeletal muscle ischemia. Clin Chem 2004; 50: 1063-65. doi:10.1373/clinchem.2003.027789

19. Van der Zee PM, Verberne HJ, Van Straalen JP, et al. Ischemia-modified albumin measurements in symptom-limited exercise myocardial perfusion scintigraphy reflect serum albumin concentrations but not myocardial ischemia. Clin Chem 2005; 51: 1744-6. doi:10.1373/ clinchem.2005. 054635

20. Gunduz A, Turkmen S, Turedi S, et al. Time-dependent variations in ischemia modified albumin levels in mesenteric ischemia. Acad Emerg Med 2009; 16:539-43. doi:10.1111/j.1553-2712.2009.00414.x 